\title{
Religion and covenantal praxis in first century Judeanism
}

\author{
Markus Cromhout (Johannesburg) ${ }^{1}$ \\ Research Associate: Faculty of Theology \\ University of Pretoria
}

\begin{abstract}
This article indicates how the two cultural features of religion and covenantal praxis helped foster or shape Judean ethnic identity in the first century CE. It focuses on socialization into the three social domains of the Temple, the synagogue and the home. In these domains, Judean ethnic identity was dominated by the requirements of the Torah. At the same time the presence of Romans, the Herodians and the Gentiles within the ancestral land helped shape Judean identity as well.
\end{abstract}

\section{INTRODUCTION}

The Judeans ${ }^{2}$ were certainly a unique people. Greco-Roman civilisation was quite successful in removing the identity and memories of the people that came within its orbit. The same cannot be said for Judeans. They remembered where they came from, and the requirements of the covenant ensured they acted accordingly (cf Hengel 1989:19). Their distinctive ethnic identity was maintained through covenantal praxis ${ }^{3}$ performed in the various spheres of life. Smith (1994:716) also explains that in

\footnotetext{
${ }^{1}$ Markus Cromhout (PhD) is a researcher and production manager for the New Apostolic Church (South East Africa District) and participates in the research project "Biblical Theology and Hermeneutics", directed by Prof Dr Andries G van Aarde, Department of New Testament Studies, Faculty of Theology, University of Pretoria. This article is based on Dr Cromhout's PhD dissertation, entitled "The reconstruction of Judean ethnicity in Q" (UP).

${ }^{2}$ In this article the traditional terms "Jews(s)" and "Judaism" are replaced by "Judean(s)" and "Judeanism". As Pilch (1997) has argued it is anachronistic to speak of "Jews" (or even "Christians") in the first century. Esler (2003:63-72) also points out that it was normal practice in antiquity that people were named after the territory from which they originated. The BDAG (2000) also prefer the terms "Judean" and "Judeanism".

${ }^{3}$ This term is used to refer to Judean customs. Things such as food, ritual immersion, dress, pilgrimage, prayers, and so forth, were inevitably an expression that its practitioner was a member of the covenant people.
} 
pre-modern eras, a distinctive religion or vision of a world religion appears to be the most potent source of ethnic persistence; but it is the social rather than the doctrinal aspects of a religion - its community-forming propensities such as rites, ceremonies, liturgy, script-and-language, sacred texts and clergy, and the value systems they transmit - that are crucial for ethnic survival in the long term.

Indeed, religion and covenantal praxis combined to make Judeanism a tenacious social entity with distinct values and which fostered a strong consciousness of difference in relation to other peoples. The cultural features of religion and covenantal praxis are consequently closely related, and hence, need to be treated together. ${ }^{4}$ The focus of this article is therefore to investigate how these two cultural features combined to foster or shape a strong Judean consciousness, particularly so in the first century CE. This process also worked in reverse. Judean identity helped to shape Judean religion and covenantal praxis. This to-and-fro process mainly occurred in three social domains. Sanders (1992:48) suggests that there were three focal points of religion: the Temple, the synagogue, and the home. Below we will trace some historical developments relevant to our period, and give an overview of prevalent covenantal praxis in each of these social domains that gave Judeans their unique identity.

Throughout it must also be taken into account that Judean ethnicity was the result of socialization. Socialization was broadly experienced on two levels. First, it is grounded in the habitus, the shared habitual dispositions of Judean social agents, which shape and are shaped by objective common cultural practices (Cromhout \& Van Aarde 2006; cf Jones 1997:87-105; Bourdieu 1977:72). Here we enter the realm of affect, the powerful influence of familiarity and customariness in social life, and the strong attachments that result from ingrained habits of thought and social practice (Fenton 2003:8990). Second, within the habitus the "sense of self" is internalized through categorization through "person-sustaining groups" such as the family, the village/town, or through society as a whole (cf Malina 1993). "Entering into ethnic identification during childhood is definitively a matter of categorization: we learn who we are because, in the first instance, other people - whether they be co-members or Others - tell us. Socialization is categorization" (Jenkins 1997:166; emphasis original). This "sense of self" may continue into

\footnotetext{
${ }^{4}$ Of course, Judean ethnic identity was also dependent on other cultural features. Very important, but not treated here, was the Judean attachment to the ancestral land. Other cultural features also not discussed here are matters such as kinship, language, and aspects of the Judean "sacred canopy", such as shared "historical" memories, myths of common ancestry, YHWH, divine election, covenant, and the Torah (see Cromhout \& Van Aarde 2006).
} 
adulthood. This would be particularly relevant to the first century personality where the individual would always see himself or herself through the eyes of others (Malina 1993).

Socialization into all three social domains, the Temple, the synagogue, and the home, introduced Judeans into a world where religion and covenantal praxis were dominated by the requirements of the Torah. But as will be shown, the presence of Romans, the Herodians and the Gentiles within the ancestral land also contributed towards shaping Judean identity, both individual and collective. We will first have a look at how the Temple, its symbolism and its rites, as well as the threats that it faced, helped to foster a Judean consciousness.

\section{THE TEMPLE: A FOCAL POINT OF JUDEAN IDENTITY}

In Leontopolis in Egypt there was the unique phenomenon of a Judean Temple built outside Jerusalem. ${ }^{5}$ About 165 BCE, Onias IV, son of Onias III, built upon an earlier shrine on the pattern of the Temple in Jerusalem but on a smaller and less grand scale. But during our period, Judeanism understood that there should be only one Temple and one place of sacrifice (Josephus, Apion 2.193). This was in contrast to the Greeks and Romans who had countless temples and sacrifices could also be made where no temples were present (Sanders 1992:49). The Egyptian Judeans, like other members of the Diaspora, therefore maintained contact with Jerusalem and went there on pilgrimage and paid their tithes and taxes due to the Temple. ${ }^{6}$ Josephus states that Judeans from Mesopotamia made "dedicatory offerings" to the Temple in addition to the half-shekel (two drachmas) Temple tax (Ant 18.312; cf Ex 30:13; Neh 10:32). Philo describes Jerusalem as the "mother-city" of the Judeans and went there on pilgrimage at least once (see Flaccus 7.46; Embassy 36.281; Providence 2.64), and writes of the zeal that Judeans had for the Temple (Embassy 210-212). The Letter of Aristeas (ca $170 \mathrm{BCE}$ ), written in Alexandria, also gives evidence for devotion to the Temple in Jerusalem. Acts 2:5-11 mentions that Judeans from various parts of the world were in Jerusalem. What occurred in Jerusalem, affected Judeans in all parts of the ancient world.

The Temple required the services of priests. Overall, Judeanism had a large hereditary priesthood that was supported by the populace. For the

\footnotetext{
${ }^{5}$ There was also a temple built on the island of Elephantine in Egypt that was destroyed around 410 BCE (Schmidt 2001:122-23).

${ }^{6}$ Cf Philo, SpecLaws 1. 133, 141-4, 153; 1.77f; Embassy 156; Josephus, Ant 14.245.
} 
Greeks and Romans priests were often taken from the elite - the priesthood was not a profession or a caste (Sanders 1992:49). So besides criticisms against the Temple and the priesthood (e. g. PsSol 8; 1 QpHab 12.8; CD $4.17-5.11 ; 6.15-16)$, support for them both was very strong, and generally people made the required gifts and offerings. ${ }^{7}$

The Temple evidently had lots of wealth, sometimes being the target of looting by Romans (Evans 1992:235-41; Sanders 1992:52, 83-85), or even a source of finance for Herod the Great and his ambitious building plans (Schmidt 2001:37-38). The Temple also enjoyed Gentile patronage. Ptolemy III, Antiochus III Sidetes, and Herod's patron, Marcus Agrippa, and the governor of Syria, Vitellius, and Gaius Caesar, the grandson of Augustus, brought their sacrifices or forms of Gentile piety. At times Gentiles also made votive offerings. It is said that at the siege of Jerusalem John of Gischala melted sacred vessels that were given by Augustus and his wife Julia, and other emperors (Schürer et al 1979:310-312). Josephus explains that when the Temple was being destroyed, the Romans found enormous amounts of money and other valuables in the treasury chambers. The priests handed over to the victors various lampstands, tables, bowls and platters of solid gold, and other treasures and sacred ornaments ( $\operatorname{War} 6.282,387-91$ ). The wealth of the Temple has even led Feldman (2001) to suggest that the Colosseum in Rome was funded by the booty taken by the Romans from the Jerusalem Temple. The first three tiers of the Colosseum were built during the reign of Vespasian (69-79 CE).

\subsection{The high priesthood}

The high priest was the principle mediator between God and the people. The present day realities, however, also necessitated that he play a mediating role between the people and the Roman authorities. According to Josephus (Ant 14.29-60), Judeans petitioned Pompey not to appoint a king over them, since it was customary for them to be ruled by the priests. As Sanders (1992:37) suggests, these Judeans preferred things to be how it was in the Persian and Ptolemaic periods: "a distant monarch, no close supervision of daily life, and local government by the high priest and his council ... the state would again become a theocracy ...". A similar request was made after Herod's death where Judeans requested Augustus not to give power to Herod's descendents, and that while the country will fall under Syria, local government will be decided upon by the Judeans themselves (War 2.80, 91). The Judeans also wanted to get rid of the high priest appointed by Herod in favour of

\footnotetext{
${ }^{7}$ Although Philo does acknowledge that there were some priests who were poor (SpecLaws 1.154).
} 
someone "more lawful and pure" (Ant 17.207-8; War 2.7). No doubt, the people were annoyed with Herod's appointment and constant change of high priests who did not have the appropriate pedigree. This also illustrates that at this time, it was more important for the Judeans to live according to the Law and for an appropriate high priest to assume responsibilities. Without an acceptable high priest, the Judean symbolic universe ${ }^{8}$ will be dysfunctional.

Even after the death of Herod it must have been annoying that the later Herodian rulers, Agrippa I, Herod of Chalcis, and Agrippa II were entrusted with the authority over the Temple, the Temple vessels and high-priestly robes, and/or appointment of the high priests (Ant 19.274-75, 297, 313-14; $20.15-16,179,203,213)$. In the period from 6 to $65 \mathrm{CE}, 18$ high priests were appointed and dismissed. During the period of Agrippa II in 50-65 CE alone, 6 high priests from different families filled the high priestly office (Schmidt 2001:36).

\subsection{Jerusalem, the holy}

Living according to the Law meant that the sanctity of the priesthood, the Temple, and Jerusalem itself had to be protected. "The more vigorous and persistent the pressure of paganism on Palestine, the more energetic was the resistance offered by [Judeanism]" (Schürer et al 1979:81). Two points in particular came into emphasis: idolatry, and the Levitical laws of purity. To avoid any association with idolatry, the Mosaic prohibition of idols was stressed (Ex 20:4f; Dt 4:16ff; 27:15). The following incidents are used as illustration.

In the last year of Herod's reign (5 $\mathrm{BCE})$, he erected over the great gate of the Temple a golden eagle. Knowing that Herod's death was near, two men, Judas and Matthaias, who had the reputation of being learned and unrivalled in the interpretation of Judean laws, encouraged young men to take the eagle down. Herod had them executed and deposed the high priest from office (War 1.651-5; Ant 17.149-67). The eagle, besides being an impure animal, also reminded Judeans of Roman domination. Furthermore, it was an unwelcome religious-cultural intrusion at a critical aspect of Judean ethnic identity. Putting up an eagle over the gate of the Temple is a bit like hoisting the American flag over an entrance to the mosque in Mecca. Here idolatry, politics and matters of identity intermingled.

\footnotetext{
${ }^{8}$ The "Judean symbolic universe" as a concept is explained in further detail elsewhere (cf Cromhout \& Van Aarde 2006; Cromhout 2007). It refers to the Judean social construction of reality, their "world" so to speak, where all Judean institutions are integrated in an allembracing frame of reference (i. e. a divinely revealed Law). It was the means whereby the Judean institutional order was legitimated, where the humanly defined reality was related to the ultimate or sacred reality. In this regard the Judean "world", or the perfect order of creation, was mainly regulated through the Temple cult and the priesthood.
} 
Judeans experienced more insults to their holy city and the Temple. When Pontius Pilate became prefect in $26 \mathrm{CE}$, he ordered that Roman troops enter Jerusalem with standards which had the bust of Caesar on them. After the peaceful protests of a few Pilate capitulated and had the standards removed from Jerusalem (War 2.169-74; Ant 18.55-9). Yet Pilate took money from the Temple treasury as well to finance the construction of an aqueduct, but this time he brutally suppressed any protests (War 2.175ff; Ant 18.60ff).

It was not that Judeans had complete paranoia over images. ${ }^{9}$ The theatre that Herod built had human busts. Some objected but it was not torn down (Ant 15.277-9). The Judeans further did not mind the use of floral motifs, particularly the vine, for the decoration of the Temple complex, for besides being symbolic for blessing, happiness and productivity (Shanks 1990:13), the Judeans would also have recognised a deeper significance. They themselves as a people were identified as the vineyard planted by God (Jr 2:21; cf Ps 80:9-12; Ezk 17:5-8). Herod also minted coins with images of wreaths, palm branches, anchors and cornucopias on them, as did the Hasmoneans. During the revolt, the rebels minted coins, depicting vines, vessels and lulavs (Sanders 1992:243). Strangely enough, according to the Mishnah, the Temple demanded the Tyrian shekels as currency, whose silver content was high and consistent, even though they had the head of the god Melqart engraved on them ( $m$.Ber 8:7). Coins with an image of the emperor also circulated freely (e.g. Mk 12:13-17), but these did not lead to riots.

A serious crisis faced the Judeans when the emperor Gaius (Caligula) decided to erect a statue of himself in the Temple. The statue was being prepared in Sidon, and news of what was about to occur spread across Palestine. Masses of people ("tens of thousands"; Ant 18.261-72; 18.305-9) came to see Petronius in Ptolemais sometime between Passover and Pentecost in $40 \mathrm{CE}$, and later in Tiberias towards the end of that same year, pleading with him to stop the desecration of the Temple. After the interventions of Petronius and Agrippa, Caligula had a change of heart, but later regretted his decision, and ordered a new statue to be made at Rome. It was to be put ashore on the coast of Palestine while on his journey to Alexandria, and secretly sent to Jerusalem (Embassy 42.331-7). It was fortunate from a Judean perspective that Caligula was murdered soon thereafter (Ant 18.307) - in January $41 \mathrm{CE}$ - and so the Judeans of Palestine was spared, for the moment, from a major confrontation with Rome.

The Judeans would have been particularly sensitive about the religious claims made on behalf of the emperor. Herod built his temples dedicated to the emperor cult. Both he and his descendants named cities after the

\footnotetext{
${ }^{9}$ Although an interesting story in the Mishnah relates that Gamaliel II visited the bath of Aphrodite at Acco (Ptolemais) based on the premise that the image of the god was there to decorate the bath - a view that did not have widespread appeal (m.AZ3:4).
} 
emperors and their wives. The residents of Palestine "were thus living in a landscape with constant reminders of the emperor's power and glory, if not divinity ... The Roman impact on Galilee and Judea was cultural-religious as well as political-economic, and it focused on the lordship of Caesar in a way that conflicted in a particular poignant way with traditional Israelite loyalties" (Horsley 1995:122).

Many Judeans, accepting the reality of Roman dominance, were prepared to accept the status quo as long as there was no outside interference with their religion and covenantal praxis. Generally any overt incursion of the emperor cult into Jerusalem invited strong opposition. Those who protested against the Roman standards in Jerusalem and Gaius' plans to erect a statue in the Temple illustrated, however, that they did not threaten war, "but were prepared to die passively rather than have the holiness of the city and the sanctuary defiled" (Sanders 1992:41). Of course, this kind of zeal or commitment was also about their own ethnic identity in opposition to Roman religious-cultural influence. Primordial sentiments flourished since important aspects of Judean culture - the Temple, monotheism, ritual purity came under attack. Ethnicity theorists inform us the stronger the opposition to aspects of a group's culture, the more salient those aspects will become in the individual's reckoning of his or her ethnicity (Scott 1990:163). Josephus in Against Apion $(2.234,271)$ places emphasis on the Judean willingness to remain faithful to the Law, something that is not found in other nations. He also remarked that Judeans were willing to die for their Torah (Apion 1.44-45; 2.232-34, 271-77; Ant 15.248), but what Greeks were prepared to die for classical Greek literature? Philo (Hyp 6.9; Embassy 192) and Dio Cassius (History of Rome 37.17.4) expressed similar sentiments. Overall, one can say that the Judeans had passion for their own ethnic identity. It was not simply about being "religious" as we would understand it in today's world - it was about being Judean. Any kind of religious activity could not be separated from personal or collective identity.

\subsection{The Temple and ritual purity}

The notions of the sacred and the profane, of the pure and impure, were important elements of the Judean symbolic universe. It was especially the role of the priests to distinguish (badal) between the two (Lv 10:10) and which had to be taught to the people (Ezk 44:23). Impurity could be acquired through transgressing the Law, but essentially had to do with the changes of status. So before we continue, what exactly did ritual purity entail? According to the Judean symbolic universe, there was a certain order to Creation; everything had its proper place. 
What is at one and the same time intact and in its place is pure, tahor. Conversely, what is impure, tame, presupposes mixture and disorder. Hence the attention given to extreme situations, to the margins, to beginnings and ends, to the frontiers of otherness in all its forms ... Thus the margins of the body are dangerous. The skin diseases, bodily secretions, the emissions of sperm and blood, excrement, by blurring the frontiers between the interior and the exterior, threaten physical integrity.

(Schmidt 2001:91)

The purity laws are found mainly in Leviticus 12 (childbirth), Leviticus 13-14 ("leprosy"), Leviticus 15 (bodily emissions), Numbers 19 (death), and Leviticus 11; Deuteronomy 14 (food). For example, after childbirth a woman was impure for either forty days (after the birth of a son) or eighty days (after the birth of a daughter). She was not allowed to enter the Temple or touch holy things. After menstruation, women were impure for a week - anybody touching a menstruant, her bed or chair was impure for a day, the same length required for purification after contact with semen. Unnatural discharge of blood (for women) and semen (for men) was considered as leading to a high degree of impurity (Sanders 1992:71-72). Death was the most severe form of "change of status". Here purification required seven days. Especially the priesthood and the Temple had to be protected from contracting corpse impurity. Even the high priest was not allowed to contract corpse impurity when his father or mother died (Lv 21:1-11). ${ }^{10}$

In order to remedy impurity, ritual immersion and sacrificial rituals were put in place to bring about a change from one status to another. As such, they were a means by which the Judean community was restored to its integrity and where everything could be established in its right place in conformity with the order of Creation (Schmidt 2001:93-94; cf Schürer et al 1979:476-77). These can also be understood as "rites of passage", and it is "particularly in rites of passage that one finds highly emotional symbolic reinforcement of ethnic patterns" (De Vos 1975:26).

The entire system of purity naturally focussed on, and was analogous to the rules for the Temple. According to Leviticus and Numbers, anyone who enters the "camp", or God's abode, must be pure. It was mainly the Temple that organised the natural and supernatural world, from which the perfect

\footnotetext{
${ }^{10}$ The notion of pure and impure also extended to other aspects of Judean life (Schmidt 2001:94). For example, clothing could not be made of hybrid fabrics, woven from wool and linen, in order to prevent the mixing of animal with vegetable (Lv 19:19; Dt 22:11). Similarly the farmer must preserve the perfect order of the Creation by not mating two different species of his livestock (Lv 19:19), by not yoking together the ox and the donkey (Dt 22:10), by not sowing different seeds together on his agricultural land (Lv 19:19; Dt 22:9).
} 
order of Creation could be regulated in every day life. The Temple would therefore play a primary role in the identity and thinking of Judeans. As Schmidt (2001:95-96) explains:

The symbolic and classificatory system that is proper to [the Temple], which is internalized by each group according to the place it occupies in the social hierarchy and the bonds that unite it to the Sanctuary, is shared by the whole community. This sharing and this internalizing lay the foundation for [Judean] solidarity.

Since the entire purity system focussed on the Temple, one can say the Temple in its architecture and planning (cf Sanders 1992:54-69; Ritmeyer \& Ritmeyer 1990) was both the centre and the symbol of the Judean symbolic universe. Preparation to enter the Temple complex already began outside. To the south opposite the main entrances was a ritual bathhouse for ritual purification, where many miqva'ot cut into the bedrock have been found. After immersion, Judeans could enter the Temple complex. Once through the gates, a tunnel leads you upwards and exits on the plaza or esplanade above. Now you are standing in the Court of Gentiles, which made up most of the area enclosed by the walls. To the south was the Royal Stoa that ran along the southern edge of the Temple complex. Anybody - subject to purification was allowed entry into the Court of Gentiles, except for menstruating women (cf War 5.226). To the north was the Temple area proper. The Court of Gentiles was separated from the area reserved exclusively for Judeans by a chest-high balustrade (1.5m or three cubits), or soreg. Next to the gates, notices in Greek and Latin were placed warning Gentiles not to go further (Ant 15.417; Philo, Embassy 212; cf Ac 21:27-31). Since the "foreigner is in the house", Schmidt (2001:109) explains that on the political level, "the strengthening of the soreg seems to be a withdrawal and focusing within the Sanctuary of the distinctions between [Judeans] and foreigners that otherwise, in the territories and on its frontiers, are blurred". For Josephus, these warnings were about the laws of purification (Ant 15.417; War 5.194). But what Judeans could not achieve politically and territorially, was symbolised by the soreg of the Temple, which became a representation of what the ideal Judean symbolic universe required. Judeans are in. Gentiles are out. As such, the strengthening of the soreg also "indicates the strengthening and extension of the purity laws to the daily life of all Israel ritually separated from foreigners" (Schmidt 2001:110).

Once past the soreg one would eventually have to pass through the Court of Women, the Court of Israelites, coming to those areas reserved for the priests alone, namely, the Court of Priests and the Temple building 
proper: Ulam, Hekal, Debir. Josephus counts seven degrees of purity from the Court of Gentiles to the Holy of Holies (War 1.26). The Holy of Holies was empty and was entered by the High Priest only once a year on the Day of Atonement.

As can be seen from the above, as one progressed from the Court of Gentiles to the Court of Priests, the courts became more and more exclusive, all related to the required degrees of purity (War 5.227; Apion 2.102-104). Purity was so important that strict measures were put into place to uphold its requirements. Only priests were allowed to build the inner area of the Temple complex. Herod had 1000 priests trained as masons and carpenters (Ant 15.390). This is clear change from Ezra 3:10, where ordinary builders lay the foundation for the second Temple. The Temple was a special place for the presence of God, and anyone who approached it had to do it with the necessary sanctity. Anything impure could not approach God's special dwelling place. The Temple complex was as a result heavily guarded. Philo explains that Levites were placed as guards at the entrances to the Temple complex, and at the entrances of the Temple itself to see that the requirements of purity were met. Guards also patrolled the Court of Israelites and the area around the Sanctuary day and night (SpecLaws 1.156). Josephus explains that during the tenure of Coponius (CE 6-9) the watch was intensified after some Samaritans scattered human bones in the Temple (Ant 18.30).

It is not just that the "ideas of holiness and separation, which allowed only what was most pure to come near, informed the entire arrangement of the temple and its rites" (Sanders 1992:70), but also the "Temple and the symbolic system of which it is the architectural expression at the same time separate, integrate and organize into a hierarchy" (Schmidt 2001:246). The Judean Temple both shapes, and is shaped by Judean notions of purity. For our present purposes, however, in the first century CE the whole of Judean society was graded according to the purity system as symbolised by the Temple architecture. First was the division of priests, Levites and Israelites, legitimate descendents of the twelve tribes and who preserved their genealogies through strict marriage regulations. On the other end of the spectrum are people tainted with defilements, such as the illegitimates, foundlings or eunuchs, who were prohibited to marry into a legitimate family. In between these extremes were a category consisting of proselytes, the illegitimate children of priests and freed slaves (Schmidt 2001:32-33).

Gentiles were initially not classified according to the purity system. The Tanak allows for Gentiles to bring their sacrifices as did the Israelites (Nm 15:14-16). This situation changed however by the late third or early second 
century BCE. Here Gentiles (along with impure Israelites) were not allowed to enter the Temple enclosure (cf the proclamation of Antiochus III in Ant 12.145-46). The same situation prevailed in Herod's temple. The schools of Shammai and Hillel apparently debated the issue of Gentile impurity. The Shammaites placed Gentiles on the level of Judean semen impurity, while the Hillelites believed that the Gentiles permanently had corpse impurity - an uncircumcised male was the equivalent of being a corpse (m.Pes 8.8)!

Generally, there seems to have been no general consensus at the time on the issue of Gentile impurity (cf Sanders 1992:72-76), although according to Schmidt (2001:241), the Sages considered the impurity of the foreigner as equivalent to that of a person with discharge.

\subsection{The sacrifices/offerings}

According to Sanders (1992:43), animal sacrifice was the simplest and most fundamental aspect of any ancient religion. Sanders gives an overview of the entire Temple operation but here we are indebted to his work on sacrifices (Sanders 1992:103-45). It may come as a shock to us moderns far removed from slaughtering animals that the priests in the Temple were expert butchers, from slitting the animals throat, to taking off the hide and removing the inward parts, to cutting the carcass into its designated parts. Generally sacrifices could consist of meal flour, wine, birds (doves or pigeons) and quadrupeds (sheep, goats and cattle). Every day the priests on duty would perform community sacrifices such as the Tamid, sacrificing a male lamb in the morning and evening along with flour, oil and wine (Ex 29:40; cf Ps-Philo 13:23). These were burnt sacrifices, where the entire animal was burnt on the altar. Such sacrifices increased in number on the Sabbath and to mark the new moon, as well as the major festivals and the Day of Atonement. Apart from these community sacrifices there were individual sacrifices brought by ordinary Judeans themselves. These would have been profoundly meaningful as the act of sacrifice was often the last moment whereby guilt and some forms of impurity were removed. Here follows a brief overview of the main sacrifices which Judeans would have brought to the Temple.

- Individual burnt offering. Leviticus 1:4 states that the individual burnt offering was for atonement. A quadruped was used (Ant 3.226). In our period, however, these offerings were thought to be gifts to God (Ant $3.243,251 ; 6.121 ; 7.389 ; 11.137 ; 15.419$ ) or to honour God (SpecLaws 1.195-7). It was all for God including the hide, but the hide went to the priest (Lv $7: 8)$. The man who offered the burnt sacrifice had to kill the animal (Lv 1:5; Ant 3.226f). 
- Sin offerings and guilt offerings. These are closely related, and in both cases the priest would receive the meat and the hide of quadrupeds. The meat was to be eaten in the Temple, on the same day, sharing it with other priests on duty (Ant 3.231; 4.75; Lv 6:29; 7:6f). The term "sin offering" is a bit misleading, and in certain cases might be understood as a "purification offering", such as that offered by a woman after childbirth. She committed no sin, but through her ritual status she deviated from the norm (= the Hebrew conception of sin) and so through her sacrifice was restored to "normality". In other words, her "citizenship" to the Judean symbolic universe was restored. Other "sin offerings" were divided into sacrifices for transgressions committed in ignorance (Lv 4:27-35) and for those committed being fully aware that it is a $\sin ($ Lv 6:2-7; SpecLaws 1.226, 235). The latter are the Biblical guilt offerings. Sin offerings made use of a lamb and a kid, and for those who could not afford it two birds could be used. If birds cannot be afforded Leviticus 5:7, 11 allow their substitution with grain, some of which would go to the priest who presumably turned it into bread. Birds were required for an abnormal "discharge" (Lv 15:14, 29). The guilt offering required a ram (Lv 6:6). Amongst other duties, a male worshipper was required to put his hand on the victim and tell the priest (or "confess") what the sacrifice was for (Lv 5:1-5; Nm 5:7). The male worshipper also killed the animal (Lv 4:29, 33; cf Ant 3.230). A woman would tell the priest or more probably a Levite what the sacrifice was for, who would in turn carry it to the altar area, but it is not clear whether the woman also laid her hand on the animal's head and "confessed" as the men did.

- The shared sacrifice (or "peace/welfare offering"). The shared sacrifice, or "communion sacrifice" (Schmidt 2001:212) had to be a quadruped (Ant 3.228; cf Lv 3:1-16). It was shared between the altar, the priest and the person who brought the offering, who in turn shared it with family and friends. The priest would take his portion home to eat it with his family (Lv 7:30-32; Nm 18:11). The devotee would take his portion, neatly butchered by the priest, and carry it out of the Temple to enjoy red meat with his friends and family. There were also sub-divisions of the shared offering: the thank offering that had to be eaten the same day (Lv 7:12); the votive offering in order to fulfil a vow; and the freewill offering. The latter two could be eaten over two days (Lv 7:16f; 22:21$3)$. The sacrifices had to be accompanied by cakes and wafers, with some leavened and some not (Lv 7:12f). One cake went to the priest 
while the offerer took the rest to be enjoyed with the meat. Both the priest and the offerer along with his family and guests had to eat the shared offering in purity (Lv 7:19-21).

\subsection{The annual festivals}

Sanders (1992:127-28) speculates that if about half of the Palestinian Judean population attended the Passover festival - which was the most popular (Ant 17.214) - and when combined with pilgrims from the Diaspora, around 300 000 to 500000 people would have been present. Other estimates place the number of pilgrims at around 80000 to 100000 , to which must be added the Jerusalem population of about 150000 to 200000 people (Ben-Dov 1990:23). We cannot be sure about the numbers, but it is plausible that tens-ofthousands of Judeans would have participated in the major festivals, and they would have been enthusiastic in doing so (cf Ps-Philo 13:4-7). It was to solve this logistical nightmare that contributed to Herod rebuilding the Temple area, and the esplanade covered the size of 12 soccer fields, stands included (BenDov 1990:24). People travelled to Jerusalem in groups. Large caravans came from Babylonia, bringing with them the Temple tax as well (Ant 17.313). Other caravans and ships brought pilgrims from Syria, Asia Minor and North Africa (SpecLaws 1.69). Galileans and Idumeans made the pilgrimage journey in groups as well (War 2.232). The pilgrims would also have had their "second tithe" money (see below) to spend. According to Deuteronomy 14:26:

Use the silver to buy whatever you like: cattle, sheep, wine or other fermented drink, or anything you wish. Then you and your household shall eat there in the presence of the LORD your God and rejoice. (NIV)

Some of the pilgrims would have found accommodation in Jerusalem itself, while many brought their own tents and stayed outside the city (Ant 17.217). The Tanak requires that all males attend each of the major festivals (Ex 23:17; 34:23; Dt 16:16). Naturally, this would only be possible for those that lived in or close to Jerusalem. Whatever males did go on pilgrimage, no doubt brought their wives and children as well. Both Josephus (Ant 4.203-204) and Philo (SpecLaws 1.70) testify to the sense of community that was engendered by these pilgrimages. This sense of community and sharing would have been taken back to their respective homes, be it in Palestine or the Diaspora. Here follows a brief discussion of the three major festivals (cf Sanders 1992:13241 ), all of which would have contributed to fostering a strong Judean ethnic 
identity. As Sanders (1992:144) points out correctly, "group identity and devotion to God went together".

- Passover (Hebrew, Pesah). Also known as the feast of Unleavened Bread (Massot), it recalled the exodus from Egypt. Originally there were two festivals, Passover and Unleavened Bread, that with time merged into one forming an eight day festival (cf Lv 23:4-8; Dt 16:1-8). On the 14th of Nisan the Passover lamb was sacrificed, while on the fifteenth (beginning at sundown) the feast of Unleavened Bread began lasting seven days (Ant 3.248f; SpecLaws 2.149f; 155). One lamb was seen as adequate for ten people (War 6.423) so presumably one of the ten would have made the sacrifice in the Temple. The roasted lamb was eaten with unleavened bread and bitter herbs (Ex 12:8). One also had to be properly attired. The loins had to be girded, with sandals on the feet and staff in hand to remember that the Israelites fled from Egypt in haste (Ex 12:11). The children also had to be instructed on the meaning of the Passover festival - God "passed over" the houses of the Israelites when he killed the Egyptians (Ex 12:26-27).

- The feast of weeks (Hebrew Shavu'ot or 'Atseret, "concluding feast"). Also called "Pentecost" or the "Day of First Fruits", it celebrated an agricultural festival. Occurring fifty days after Passover, it was identified mainly by the offering of new wheat. Two loaves of bread were made from the first wheat of the harvest, and offered as "first fruits" (Lv 23:1521; cf Nm 28:26-31). This inaugurated the period where Judeans brought their offerings of first fruits to the Temple. Here God's ownership of the land was declared, as well as his grace that allowed the land to bring forth food. In addition, it was a time to remember and give thanks for God's deeds on behalf of Israel: the election, the covenant and the exodus (cf Dt 26:1-15).

- The feast of booths/Tabernacles (Hebrew, Sukkot). It is an autumn festival that began five days after the Day of Atonement, being second to Passover with regards to the number of pilgrims. It is prescribed that for seven days Israelites will live in booths (Lv 23:42). One more festival day (where work was forbidden) was added, making it in effect an eight day festival (Lv 23:33-36). The booths or tabernacles were made of "branches from olive and wild olive trees, and from myrtles, palms and shade trees" (Neh 8:15). The residents of Jerusalem probably built them on the roofs of their houses, while pilgrims built 
them outside the city walls. Also an agricultural festival, it marked the conclusion of the harvest season. It was "a showy and happy occasion with something of a carnival spirit. Worshippers carried lulavs, made of branches from palm, willow and myrtle trees, to which a citron (a citrus fruit) was attached ... There was flute playing and dancing by night" (Sanders 1992:139; cf Lv 23:40; Ant 3.245; m.Sukk 5:4). The Hallel was apparently sung on each of the eight days and during the singing the worshippers shook their lulavs ( $m$.Sukk 3:9; 4:8). A plethora of community sacrifices were made ( $\mathrm{Nm} 29: 12-34$; Ant 3.246), while study of scripture was probably an important element during the festival (Dt 31:10f; Neh 8:17f). Leviticus also connects this festival to the exodus (Lv 23:42f).

\subsection{Tithes, offerings and the Temple tax}

The Tanak, particularly the Torah, has no uniform prescription on tithing and offerings. What was tithed and how much developed over time, and here again we are indebted to Sanders (1992:146-57) and will follow his reconstruction of the tithing and offering system that was in place in the first century. All these contributions existed to support the priests and Levites who were not allowed to "inherit the land" (Nm 18:20-31; Dt 18:1-2), although evidently there were those who did own land but refrained from working it themselves. But the onus was on ordinary Israelites to support their priests and Levites who were to serve in the Temple (TLevi 9:4; Jub 14:25; 32:1015). There were strict biblical requirements for the priests and their families when they ate the tithes and offerings. They had to be in a state of ritual purity (Lv 22:4-7; Nm 18:13), while ordinary Israelites were also expected to handle and eat second tithe in purity (Dt 26:13-14).

- The tithe, literally means "one-tenth". In our period the requirements of Deuteronomy 14; Leviticus 27 and Numbers 18 (cf Neh 10:37-39) were combined to form what Sanders calls the fourteen tithe system in a seven year cycle. Every seventh year, the sabbatical year, no tithes were offered as the land was given an opportunity to rest. In the other years there were at least two tithes, the tenth of all agricultural produce - not animals - that went to the Levites (who then gave a tenth of what they received to the priests), and the so-called "second tithe", money that had to be spent in Jerusalem especially during pilgrimage festivals. Every third and sixth year there was a third tithe, which was given to benefit the poor. Josephus understands that Moses required the two tithes per year and the third tithe every third and sixth year (Ant 4.69, 
$205,240)$, illustrating that the fourteen tithe system was used. Priests and Levites collected the tithes themselves (Neh 10:37f; Life 63). Based on the debate of the Pharisees, not all people were necessarily enthusiastic about giving the Levites their portion, although the ordinary people were inclined to give the priests the one tenth of the first tithe as required.

- First fruits. This category involves food (first produce and firstlings), money (redemption of non-edible firstlings) and fleece. In the case of firstlings, the requirements of Exodus 13 and Numbers 18 prevailed, where all male firstlings of animals belonged to God, that is, it went to the priests. All the firstlings of impure animals (donkeys, horses, camels etc) were redeemed for one and a half shekels, while a first born son was redeemed by the father for five shekels (Ant 4.71; cf Nm 18:15f). The first fruits of produce required the first of everything that the land produced (Ant 4.70). First fruits involved both primary and secondary produce: "both raw food (grain, grapes, olives and the like) and the first things made from it (cakes, wine, and oil); both the firstborn lamb and the first of the year's wool" (Sanders 1992:152). In our period the distinction of Leviticus 23 was followed, where the offering of the first fruits of the harvest occurred on the second day of Unleavened Bread (where a sheaf of barley was waved before the altar), and where the first cakes or loaves were offered at the Feast of Weeks around fifty days later (Ant 3.251-52). Since the Feast of Weeks was not that popular, it probably worked out that most people offered their first fruits at the Feast of Booths. Those who brought their first fruits had a required avowal to say that concerns God's gift of the land and the exodus (Dt 26:1-11).

Sanders also discusses the heave offering, or terumah. Neither Josephus nor Philo mentions it, and in Numbers 15:20 and 18:11 the noun terumah is used to refer to the primary offerings, the shared sacrifice and first fruits. The LXX usually translated the heave offering as "first fruits", nevertheless, terumah may be a separate offering in Nehemiah 10:37, 39, and this is the way that the rabbi's understood it (m.Ter 4:3).

- The Temple tax. This contribution did not go towards the priests, but was used to pay the Temple costs, especially the community sacrifices. According to Exodus 30:13-16, every Israelite male twenty years old 
and above was required to pay a half shekel in support of the tabernacle, a tax that was required to be given only once in a lifetime. Nehemiah 10:32 requires an annual tax of one third shekel. Eventually it was understood that that the Tanak requires an annual tax of one half shekel (= two drachmas), payable by each adult Judean male. The preferred currency was the Tyrian half-shekel. After the Temple was destroyed, the didrachma or half-shekel was changed into a Roman tax, the humiliating fiscus Judaicus, but the tax base was broadened to include women and children as well. All Judean men and women between the ages of three and sixty-two were taxed. To add insult to injury, the money was paid to the temple of Jupiter Capitolinus in Rome (War 7.218; Dio Cassius 66.7). This tax was eventually abolished under Nerva (96-98 CE).

\section{THE SYNAGOGUE}

In Hebrew, the term for synagogue is beth knesset, "house of assembly". Generally there is no certainty about the history of the synagogue, yet it is regarded as an important element in Judean life and worship in the first century. Some question marks have been raised, however, as to its prevalence as a building. We will first review the textual and archaeological evidence before any conclusions will be drawn.

\subsection{The synagogue: A building or assembly of people?}

Let us first review the textual evidence. The Gospels speak of a $\sigma v \nu \alpha \gamma \omega \gamma \eta$ in Nazareth (Mt 13:54; Mk 5:2; Lk 4:16) and Capernaum (Mk 1:21; Lk 7:5; Jn 6:59). The amounts in larger cities were apparently greater, such as Jerusalem (Ac 6:9; 24:12), Alexandria (Philo, Embassy 132) and Rome (Embassy 155-8). Most often Acts makes use of $\sigma \nu \nu \alpha \gamma \omega \gamma \eta$ for assemblies in the Diaspora, while it describes that Paul found Judean synagogues everywhere on his travels in Asia Minor and Greece (Ac 13:14; 14:1; 16:13, 16; 17:1, 10, 17; 18:4, 7, 19, 26; 19:8), Cyprus (Ac 13:5) and Damascus (Ac 9:20). Josephus mentions a synagogue in Caesarea (War 2.285-290), on the Phoenician coast (War 2.185-90) and a magnificent synagogue in Antioch (War 7.44-5) suggesting that there was more than one.

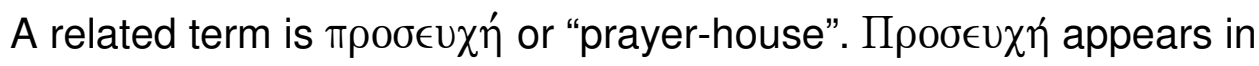
Josephus (Life 277, 280, 290-303; in Tiberias) and Philo (Embassy 132, 155f; in Alexandria and Rome), 3 Maccabees 7:20 and in the New Testament (Ac $16: 13,16)$. Philo also speaks of people attending "schools" on the Sabbath (SpecLaws 2.62f) where Judeans received instruction in the Law. 
Alternatively, these two Greek terms are used for Judean assemblies of people and/or places of meeting in the Diaspora and in Palestine. The earliest evidence comes from Egypt, where documents and inscriptions dating from around the middle of the third century BCE and onwards make mention of $\pi \rho \sigma \sigma \in \cup \alpha i^{\prime}$ although $\sigma u \nu \alpha \gamma \omega \gamma \eta^{\prime}$ in the Diaspora initially did not have this meaning. It signified the congregation (of people) and not the building. It is

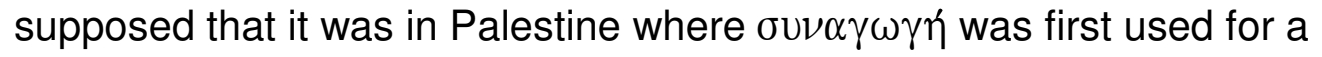
"meeting house" - although it is also claimed that there is no realistic distinction between these two Greek terms (Schürer et al 1979:425, 439-447). It is thought that in view of the importance of Sabbath meetings, "it must be assumed that at least one synagogue stood in every town of Palestine, even in the smaller places" (Schürer et al 1979:445), a view similarly held by Sanders (1992:198).

Horsley (1995:222-27; 1996:131-53) has rejected the usual scholarly construct of synagogues in Palestine and argues that $\sigma \nu \nu \alpha \gamma \omega \gamma \eta$ i or the Hebrew knesset refers more to the assembly of people than a structure. In the Diaspora $\pi \rho 0 \sigma \epsilon \cup \chi\{$ denotes a building wherein the congregation meets.

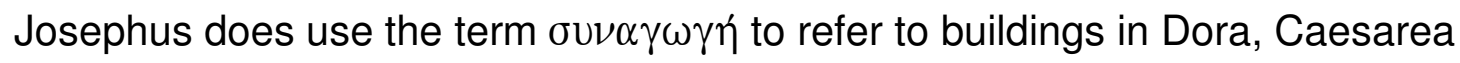
and Antioch, but these cannot be used to argue for the existence of "synagogue" buildings in Judean or Galilean villages. These structures clearly also have a socio-political dimension as a centre for the local community in addition to its religious dimension, as does the prayer-house in Tiberias. The brunt of Horsley's argument seems to be that there is no justification for the standard reading of $\sigma \nu \nu \alpha \gamma \omega \gamma \eta$ in the New Testament as a religious building. The places of meeting were according to him the local village or town square.

One can agree that the synagogue (be they buildings or merely assemblies of people) did not purely perform a religious function. A political meeting was even held in the great $\pi \rho 0 \sigma \epsilon \cup \chi \eta$ of Tiberias (Life 280). Shanks (2001:52-53) states that before 70 CE "a synagogue was more like a community center. It was a place where groups of [Judeans] assembled for social functions and political matters, where they kept their money, where they collected and dispensed charity, where they judged disputes - and especially, where they studied the sacred texts. Probably not where they prayed, however [but cf Mt 6:5]". Otherwise the New Testament makes mention of

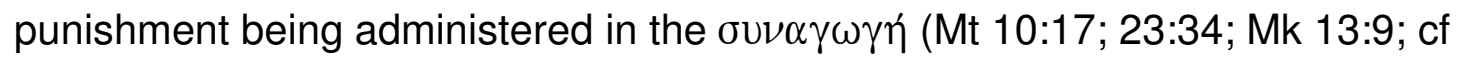
Ac 22:19; 26:11). Besides punishment, members could also be excommunicated from the assemblies, as testified to in the time of the New Testament (Lk 6:22; Jn 9:22; 12:42; 16:2). Clearly then, the first Messianists 
were seen as undermining the Judean symbolic universe, posing a threat to the integrity of Judean ethnic identity.

In addition, Horsley's argument above is to a degree ignoring or dismissing the available evidence. There is of course the Theodotus Inscription found near the Temple Mount, which refers to a synagogue that could have been built as early as 100 BCE (Shanks 2001:51). The inscription itself dates to the first century CE (Shanks 2001:51; Porter 1994:145) and reads in part: "Theodotus son of Vettenus ... rebuilt this synagogue for the reading of the Law and the teaching of the commandments ...". Clearly some or other building is referred to. According to Kloppenborg (2006:251-79), both the provenance and the palaeography of the inscription point to a Herodian or early Roman dating (i e prior to $70 \mathrm{CE}$ ). There is also the Benghazi inscription (in Cyrenaica), dated to 55/56 CE, where $\sigma \nu \nu \alpha \gamma \omega \gamma \eta$ ' refers to both the congregation and a building (Kloppenborg 2006:245-46). But as Kloppenborg (2006:278) argues, the Theodotus Inscription confirms that $\sigma \nu \nu \alpha \gamma \omega \gamma \eta$ "was used of buildings not only in Egypt and Cyrenaica but also in early Roman Palestine". Other archaeological evidence for Palestine is meagre, but it does exist. Synagogue buildings have been found identified at Masada and Herodium, the two desert fortresses that were built by Herod the Great, and at Gamla in the Golan Heights. In addition there is a synagogue at Capernaum (cf Lk 7:5) and Chorazin (Strange \& Shanks 1990), and a house-synagogue in Caesarea (Bull 1990:115). Archaeologists have also suggested that they have found synagogue buildings at Jericho and at Migdal (or Magdala), both dating to the first-century BCE, although whether the structure at Migdal was in fact a synagogue is disputed, however (Shanks 2001).

According to Cohen (1987:114) "the synagogue is an amalgamation of a prayer-house, which apparently originated in the Diaspora in early Hellenistic times; A study house or school, which apparently originated in Israel also in early Hellenistic times; and a meeting-house, which served the different needs of Diaspora and Palestinian [Judeans]. By the first century these diverse elements had not yet united to form a single type". But another process is also likely. The various buildings/assemblies already had various functions, and only much later did they develop to have a more religious purpose. In summary the evidence is meagre, but there is evidence for synagogue buildings, while Horsley's objection will be noted in that $\sigma \nu v \alpha \gamma \omega \gamma \eta$ ' in some cases might rather refer to an assembly of people. Beyond the family, the assemblies/synagogues would have formed the most important social and cultural form of the local community, and so would have promoted a strong group identity of being Judean. 


\subsection{Teaching the law and the prophets}

In post-exilic Judeanism the custom of Sabbath readings in the assembly took shape. These Sabbath meetings were not religious worship in the narrow sense, but also contained instruction in the Torah. By the first century CE obedience to the Torah was an essential part of Judeanism (cf Apion 2.276-7; 1.43). Besides instruction in the Torah, Luke 4:17 gives evidence of the haftarah, or reading of the prophets. Both Josephus (Apion 2.175-78) and Philo (Creation 128) testify that there were regular Sabbath services in the assemblies and it was an important means of maintaining the ancestral religion. The Law and the prophets were read and elaborated upon every Sabbath wherever Judeans lived in the Diaspora, the normal liturgical language most probably being Greek (Schürer et al 1979:424; 1986:142). The reading from the Torah and the prophets is also in evidence in the New Testament (Lk 4:17; Ac 13:15). In Palestine a reading from the scriptures was sometimes accompanied by a translation, or targum, an ongoing rendering into Aramaic (cf Schürer et al 1979:452-453).

Part of the proceedings was a spiritual sermon, which in Philo appears as almost the most important aspect of the gathering (SpecLaws 2.62; Moses 2.216; Eusebius, PrEv 8.7.12-13). Here Bible passages were expounded and given practical application. This teaching function of the assemblies is corroborated by the New Testament (Mt 4:23; Mk 1:21; 6:2; Lk 4:15, 4:20 ff; $6: 6 ; 13: 10 ; \mathrm{Jn} 6: 59 ; 18: 20 ;$ Ac 15:21 et al), where it was the primary activity of Jesus and Paul. Josephus (Apion 2.175) also makes reference to the teaching function of the assemblies. Prayer is mentioned in Matthew 6:5. Study of scripture in the assemblies was therefore common to Judeans, both in Palestine and in the Diaspora (Cohen 1987:113).

According to Cohen, with the development of the synagogue it meant the Temple was not the only place where people could communicate with God. The development of prayer and Torah study was an alternative means for reaching God. The emergence of scribes and sages meant that the priesthood no longer had the monopoly on religious truth. This means that during the Second Temple period Judeanism was "democratised". It was far more concerned with the piety and fate of the individual than the pre-exilic Israelite religion was (Cohen 1987:75). Sanders (Sanders 1992:181) has a different approach. There were approximately 18000 to 20000 priests and Levites, as opposed to 6000 Pharisees. There were thousands of priests and Levites that probably lived in Jerusalem, while the rest lived in other cities of Judea and Galilee. Since the priests and Levites were only on duty one week in every twenty-four (as they were divided into twenty-four "courses"), plus during the pilgrimage festivals, they were free most of the time to conduct their own affairs. Thus it is likely that they served in their towns and villages as 
teachers and magistrates. So in most parts of Palestine they would have assumed their traditional leading roles, which included teaching and enforcing the Law and serving as judges and scribes. In these tasks they were assisted by the Levites (Neh 8:7-9; 1 Chr 23:2-6; 2 Chr 17:7-9; 19:8-11) (Sanders 1992:170-71). Deuteronomy places the responsibility of the Law into the hands of the priests (Dt 17:18; 31:9), and Ben Sira regarded the priests as the nation's teachers (Sir 45:17). Josephus regarded the priests as the nation's rulers and judges (Ant 4.304; 14.41; Apion 2.165) - the system was a "theocracy" (Apion 2.184-7). Sanders' (1992:173) basic argument is that the priests maintained their traditional roles but they no longer had a monopoly over them. Inscriptional evidence supports the textual evidence that priests maintained their traditional roles. Sanders refers to the first-century Greek inscription in Jerusalem that refers to a Theodotus, a third-generation priest and archisynagogue ("ruler of the synagogue") ${ }^{11}$ who built a synagogue "for the reading of the law and for the teaching of the commandments". Here three generations of priests were rulers of the synagogue (Sanders 1992:176). Philo informs us that Sabbath instruction was led by a priest or elder (Hyp 7.12f). Overall Sanders (1992:181-82) concludes

that it is unreasonable to suppose that the small number of Pharisees, most of whom probably worked from dawn to dusk six days a week, also served their communities as lawyers and scribes, while the large number of priests and Levites, who were on duty in the temple only a few weeks a year, who could not farm, and who were educated in the law, did nothing. It is much more likely that ordinary priests and many of the Levites put their learning to good use and served as scribes and legal experts ... Priests and Levites were the employees of the nation for the purposes of maintaining the worship of God in the temple, and teaching and judging the people.

The understanding of the Pharisees may be a bit questionable so far as their work hours is concerned (cf Baumgarten 1997:51), but one can agree with Sanders (1992:201) that the priests were likely to be involved in community study and teaching in the synagogue (cf Stegemann \& Stegemann 1999:140). If this was the case, which is very likely, the Temple and its symbolic meaning and ability to shape identity would also extend to outlying Judean

\footnotetext{
${ }^{11}$ Mark 5:22, 35-38; and Acts 13:15; 18:8, 17 and others also refers to an $\dot{\alpha} \rho \chi\llcorner\sigma \nu \nu \alpha ́ \gamma \omega \gamma o \varsigma$ - is it likely that they were priests as well? It is a distinct possibility. Compare Horsley (1995:232), however, who speaking of Galilee, suggests that local governance of village and town were provided by local assemblies (and courts) "operating more or less democratically" with the

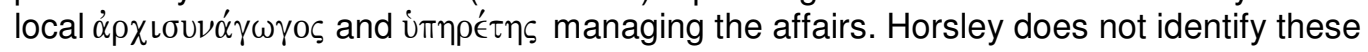
officials as priests, nor does he understand Galileans as Judeans for that matter.
} 
communities. The priests and the Temple were not that sidelined as Cohen suggests. Similarly Schmidt (2001:263) argues that already before $70 \mathrm{CE}$

the synagogal institution is a bearer of the thinking of the Temple. Far from being a sign of a decline of the Temple, it is one of the principal vehicles of the extension to the whole of [Judean] society of the ritual prescriptions expressing the categories of the sacred and the profane, of the pure and the impure, as well as the mode of classification proper to the thinking of the Temple. As such, the synagogal institution appears as a manifestation of the extension in the strongest sense of the term - of the Sanctuary.

Indeed, the synagogue or assembly would have been a perfect tool for the maintenance of the Judean symbolic universe. The Temple and its "thinking" was the focal point, but it was complimented by instruction in the Torah, correction, and even excommunication. Here we must be reminded of the social function of religion, and its ability to shape communities (Smith 1994:716). Communal solidarity would have been engendered and of course, a shared ethnic identity.

\section{THE HOUSEHOLD}

Everyday life for the Judean was regulated by requirements of the Torah. They shaped mutual relationships, the rhythm of every day life, the Sabbath and feasts, and work. "In particular, the consciousness of [Judean] identity was reinforced through the religious structuring of time, daily prayers, the study of the Torah, and, not least of all, purity and food regulations ..." (Stegemann \& Stegemann 1999:142). Here we will specifically concentrate on how a consciousness of Judean identity would have been shaped at home. The home was the primary place of worship or the place used most frequently (Sanders 1992:197; cf Sanders 2002:121). Horsley (1995:129) points out that

Religious formation and expression operated at more than one level, that of family and local village community being at least as important as that of the Jerusalem Temple for the vast majority of people, who lived in outlying towns and villages.

We must therefore always bear in mind the close association that exists between the family and the local community, but the home would be the primary area of early socialisation and where "habitual dispositions" (Jones (1997:87-105; Bourdieu 1977:72) will be formed and "categorization" (we know who we are because other people tell us; see Jenkins 1997:166) will 
take place. So for the average Judean child of the first century, what would he/she be socialised into?

\subsection{The Shema, dress and prayers}

The saying of the Shema, the biblical passage in Deuteronomy 6:4-9, was fundamental to Judean life and worship. It began with the confession: "Hear [shema], O Israel: The LORD our God, the LORD is one. Love the LORD your God with all your heart and with all your soul and with all your strength" (vv 45). The Shema encouraged Israelites to place the commandments of God upon their heart, hand, forehead and on the doorpost and the gate. The commandments should also be taught to children and be remembered before sleep and on waking up (Dt 6:6-9). The commandments to be remembered was especially the Ten Commandments of Deuteronomy 5 , but all the commandments are referred to. The mishnaic rabbi's simply took it for granted that Judeans recited the Shema (along with daily prayers) twice a day, at morning and at evening (m.Ber 1:1-3). The importance of the Shema is highlighted by other Judean customs. Some of the instructions contained therein were taken literally by the second century BCE and gave rise to the custom of wearing tefillin (phylacteries) and fixing mezuzot to doorposts (Cohen 1987:74).

According to Sanders (1992:123) Judeans would have dressed as other people did in the Greek-speaking world. Yet they could be distinguished by them wearing tefillin as discussed above, and also by tassels (Schürer et al 1979:479-481). The tassels (tsitsit) were attached to the hem of garments (on the four corners) and were made of blue or white wool, and is mentioned in Numbers 15:37-41 and Deuteronomy 22:12. ${ }^{12}$ This is to be worn by every Israelite and it had the purpose of when looking upon them, to remember the commandments and to do them. In a sense the ordinary Israelite was wearing a priestly garment. Israel as a whole is a "kingdom of priests and a holy nation" (Ex 19:6), so the tassel was not only a reminder of the commandments, but by observing the commandments, they also strive for a life of holiness (Milgrom 1983).

The Pharisees were accused of making their phylacteries broad and their fringes long (Mt 23:4). "Pharisees wore the same clothes as everyone else, with only the minor statement of special identity expressed through broad phylacteries and long fringes" (Baumgarten 1997:102, emphasis original). The Letter of Aristeas testifies to these Judean customs and the importance of the Shema. Accordingly God commanded the following:

${ }^{12}$ Cf Ps-Philo 16:1; Mt 9:20; 14:36; 23:5; Mk 6:56; Lk 8:44 and LXX and TargNm 15:38. 
... in our clothes he has given us a distinguishing mark as a reminder, and similarly on our gates and doors he has commanded us to set up the "Words," so as to be a reminder of God. He also strictly commands that the sign shall be worn on our hands, clearly indicating that it is our duty to fulfil every activity with justice ... He also commands that "on going to bed and rising" men should meditate on the ordinances of God ... (LetAris 158-60).

Accompanying the saying of the Shema, daily prayers were also offered. Josephus states that Moses required thanksgiving prayers when waking up and going to sleep (Ant 4.212). It is said of Judeans: “... at dawn they lift up holy arms toward heaven, from their beds, always sanctifying their flesh with water" (SibOr 3:591-94). Washing of hands during prayers is mentioned in the Letter of Aristeas 305-6. Some offered evening prayers during the time of the last sacrifice in the Temple (e. g. Jdg 9:1). The pseudepigrapha depict the Biblical heroes as praying often (see Sanders 1992:202). There were also thanksgiving prayers (Berakhoth) before and after meals (Dt 8:10). It is also argued that the Shemoneh Esreh, the prayer required from every Israelite three times a day, though more recent, is fundamentally still very old, the foundation of the prayer preceding 70-100 CE (Schürer et al 1979:455-463). Prayer was also at times accompanied by the practice of fasting ${ }^{13}$ (cf Schürer et al 1979:481-484, 455).

The Shema further requires that the commandments of God be taught to children. Together with theoretical instruction went training in religious practice. "For although children were not obliged to fulfil the Torah, they were nevertheless habituated to it from the earliest years" (Schürer et al 1979:420). Rabbinical writings explain that parents were obliged to make their children keep the Sabbath rest. Children were gradually accustomed to keep fasts, such as on the Day of Atonement. They were further required to recite the Shemoneh 'Esreh and grace at table. Young boys were to go to the Temple at festivals and were also required to observe the Feast of Booths/Tabernacles. As soon as the first signs of manhood appeared, he had to keep the whole Law (the expression bar-mizwah is attested in the Talmud; b.BM 96a). Later it was standardised and the young Judean reached legal majority at the age of thirteen (Schürer et al 1979:421).

\subsection{Sabbath observance}

Josephus (War 4.580-83) informs us that a priest stood on one of the Temple Mount towers to blow a trumpet in order to announce the start and the end of the Sabbath, a statement supported by archaeological evidence (Ben-Dov

${ }^{13}$ Cf TLevi 9:4; Jub 14:25; 32:10-15; Mt 6:5; 9:14; 15:7-8; Mk 2:18; 7:6; 12:40; Lk 5:33; 20:47. 
1990:29-30; Ritmeyer \& Ritmeyer 1990:40-43). Celebrated by all Judeans wherever they were, the Sabbath was to be kept as a day of rest (Ex 20:8-11; Dt 5:12-15). The Maccabean crisis ensured its growing status for Judean selfunderstanding (1 Mac 1:43; Jub 2:17-33; 50:6-13; Ps-Philo 11:8). It was one of the most recognisable and unusual customs of Judeanism, sometimes even imitated by Gentiles, who like Judeans, marked the day by abstaining from doing work and having lamps burning (Apion 2.282). According to Jubilees in particular, divine election went hand in hand with the requirement to keep the Sabbath (Jub 2:19;), a right that was granted to no other nation (Jub 2:31). Transgressors must die (Jub 50:7-8, 12-13).

In the Pentateuch there is a short ban on work on the Sabbath that enters almost into no detail (Ex 16:23-30; 20:8-11; Lv 23:3; Nm 15:32-6; Dt $5: 12-15)$. The later rabbi's felt obliged to be more exact and specified thirtynine activities that were not allowed on the Sabbath ( $m$.Shab 7:2; cf Jub 50). In the Pentateuch, for example, ploughing and reaping is forbidden (Ex 34:21), the boiling and baking of food (Ex 16:23), as well as lighting a fire (Ex 35:3). The rabbinic prohibition of carrying anything from one domain to another was inspired by Jeremiah 17:21-23, although the idea could be stretched to mean a lot of things (cf Jub 2:29-30; 50:8).

Other rulings included the restriction on how far one may journey on the Sabbath (Ex 16:29; cf Ac 1:12). Even the Romans did not recruit Judean soldiers because of the incompatibility between the Sabbath and Roman military requirements (Ant 14.226). There was a basic rule that the saving of life took priority over Sabbath rulings. This was already in place from the time of the Maccabean revolt when a group of Hasideans were attacked by Gentiles, but rather chose to die than to fight on the Sabbath (1 Mac 2:34-8; Ant 12.6.2.274). As a consequence, it was decided that the sword could be taken in defence on the Sabbath (1 Mac 2:39-42), but this ruling was only followed in extreme cases (Schürer et al 1979:474).

\subsection{The Day of Atonement}

This special day on the Judean calendar is treated here since for most Judeans it was a day spent in and around the home. The Day of Atonement (Hebrew, Yom Kippur) is the only fast prescribed by the Tanak. It was not a time for pilgrimage, but a communal day of worship, in thought and spirit being connected to what took place in the Temple. It was a day for the atonement of $\sin$, and the sacrifices made by the High Priest in Jerusalem was made for all (Lv 16). The goat "for Azazel" was brought in, whereupon the high priest laid his hand and confessed the sins of Israel as a whole. An 
appointed person then took this "scape-goat", which carried the sins of Israel, out of the city and into the wilderness (Lv 16:15-22).

\subsection{The purity of food}

The issue of food became an important factor in Judean life from the Maccabean revolt onwards (Dunn 1990:193). In comparison with the holy food (teruma) of the priests and their families, the food of lay Israelites were made from hullin (or profane) products, which nevertheless, had to conform to the rules of the kashrut, that is, the prohibition of unclean animals (land and marine hybrids, wild animals, vultures or predators), the prohibition of blood, the ritual slaughter of clean animals, and separation of milk and meat (Schmidt 2001:217).

Regulations were already in place to distinguish food that was allowed for consumption from "impure" food that was disallowed (Lv 11:1-23; Dt 14:321). Judeans were allowed to eat only a few animals, while the fatty parts and blood was forbidden. It was a strict requirement that the blood be drained (from the meat of clean animals) in accordance with the requirements of the Torah (Lv 3:17; 7:26-27; 17:10-14; Dt 12:16, 23-24; 15:23; Jub 6:7-10; $21: 6$, 17-18; SibOr 2:96). Quadrupeds that could be eaten were those that chew the cud and have cloven hoofs (Lv 11:3-7; Dt 14:6-8). This includes cattle, sheep and goats, as well as wild goats and deer. Pork was forbidden, a well known Judean characteristic in the ancient world. Fish with fins and scales could be eaten (Lv 11:9), as well as several birds, but birds of prey were prohibited (Lv 11:13-17). Insects and "swarming things" (serpents, lizards, weasels etc) were likewise forbidden, but locusts, crickets and grasshoppers, who have their legs above their feet were allowed (Lv 11:20-45). It is also probable that by our period it was prohibited to cook or serve red meat (and fowl) together with milk and cheese (Sanders 1992:217). These regulations naturally had profound implications for social life. Josephus says that food is the starting point of the Law and connects directly to social relations (Apion 2.173-74). Processed food was similarly imprinted with the social order (Baumgarten 1997:92). Unclean food, or the food of Gentiles must be avoided, because it was not slaughtered properly or offered to idols (JosAsen $7: 1 ; 8: 5 ; 3$ Mac 3:4, 7; 4 Mac 1:34; SibOr 2:96). The production and consumption of food was another way in which the Judeans maintained their symbolic universe. It determined who was in and who was out. Regulations concerning food were therefore primary boundary markers in Judeanism, even more so in the sects whose members began to regard fellow Judeans as "outsiders". The Pharisees' restrictions on food were less stringent than those of the Qumran Covenanters/Essenes. Yet they maintained boundaries around themselves 
through their food regulations - in the hierarchy of purity, they placed themselves above normal Judean society (Baumgarten 1997:92-97).

Hand in hand with type of food you ate was the issue of how you stored, prepared or served it. Generally, regulations governed the use of eating utensils (cf Mt 15:2; 23:25-6; Mk 7:2-5; Lk 11:38-39), and the type of water to be used, all elaborated upon in the twelve tractates of Seder Tohoroth in the Mishnah (Schürer et al 1979:476-477). Jars, cooking pots, jugs, plates, bowls and cups had to satisfy the laws of purity. Stone vessels were widely used, as it was believed to be impervious to contracting impurity (cf $m . K e l 10: 1 ; m . P a r$ 3:2). Pottery vessels, on the other hand, had to be destroyed after it came into contact with an impure substance or object (Avigad 1990). Metal and glass vessels could be repurified, however, which brings us to the matter of ritual immersion.

\subsection{Ritual immersion}

Ritual immersion (and washings) developed to be quite a distinctive trait of first-century Judeanism, particularly so among sectarians. The Sadducees carried on with the Biblical tradition. The Essenes transferred to their community the requirements of the Jerusalem Temple. It is argued that the Pharisees "centred the laws of purity on the table, with the idea of eating their everyday meals in the same state of purity as that required of the priests in the Temple" (Schürer et al 1979:475 n 63; cf Neusner 1973), a position with which Sanders (1992:380-451) disagrees.

Mark 7:3-4 relates directly to Pharisaic eating practices (Baumgarten 1997:97). Mark 7:3 (cf Mt 15:1-20) says: "The Pharisees and all the Judeans do not eat unless they give their hands a ceremonial washing, holding to the tradition of the elders."

This requirement in the time of Jesus is said to be only really applicable to the haberim or Associates, ${ }^{14}$ and Schmidt (2001:235) suggests that this rite was not simply to achieve purity as an ideal, but marked a passage to enter a space or time of a greater or lesser holiness. Thus the hullin food is not necessarily seen as "holy", but the time in which it is consumed is, separated from profane space and time. Otherwise Mark 7:4 continues:

When they come from the marketplace they do not eat unless they wash (or immerse, $\beta \alpha \pi \tau i \sigma \omega \nu \tau \alpha \iota$; other mss read "purify"). And they

\footnotetext{
${ }^{14}$ Cf Schmidt (2001:232-34), who explains that the "Associates are mainly lay persons organized in associations in which they commit themselves to respect scrupulously the purity regulations and the tithes as they have been decreed, already before the destruction of the Temple, by the Sages of proto-rabbinism."
} 
observe many other traditions, such as the washing of cups, pitchers and kettles.

Here to wash/immerse themselves when they come from the marketplace involves a purification of the whole body, not just the hands as in verse 3 . Immersion is also mentioned in Luke 11:38. A Pharisee invites Jesus to eat with him. He is surprised that Jesus did not first immerse ( $\left.€ \beta \alpha \pi \tau \tau^{\prime} \sigma \theta \eta\right)$ himself before the meal (the text has got nothing to do with the washing of hands: 0

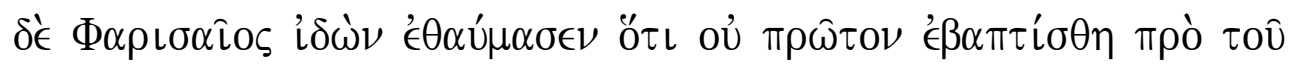

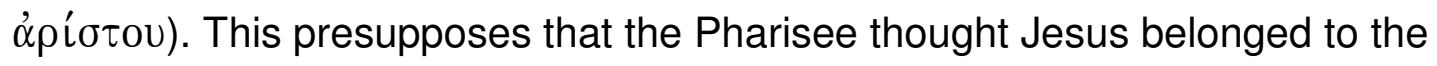
same group, or at least was willing to conform to Pharisaic purity standards. Baumgarten states that it is fair to conclude that such "immersion was deemed necessary because Pharisees believed that they had contracted impurity while in the market, from 'bumping into' people of indeterminate status, [Judeans] and/or [non-Judeans]. Eating could only take place after the elimination of this impurity, and in the company of others who were also pure ..." (Baumgarten 1997:99).

If the above is correct, Pharisees could only eat with other Pharisees, or with those who maintained their standards, even if only temporarily (Baumgarten 1997:100). Cohen (1987:130) similarly explains that "the laws of purity prevent normal social intercourse between those who observe them and those who do not. Those who observe the laws cannot share the table, utensils, or food of those who do not. They must avoid physical contact ... with those who are impure." Even so, we need to draw attention to the suggestion of Schmidt (see above) in that the washing of hands before the eating of profane food served a purpose in that the participants entered a sacred space or time period. Although Schmidt does not make this connection himself, the same might have been part of the intention when it came to ritual immersion of persons and their eating utensils before meals. Maybe it was not simply just for the sake of achieving purity for its own sake.

Overall, there was a development in some Judean quarters with regards to the way you eat your food. The old table system, which prevailed during the Hasmonean period, was bipartite; the common meal of the priests was separated from that of the common meal of lay persons.

In the Roman period, with the entry of the foreigner into the house, a new table system is introduced. For the haberim and more broadly those who put into practice the new prescriptions of the Sages as regards tithes and ritual purity, the frontier that separates the order of priests from that of the laity tends to get blurred. Set 
apart from the profane activities, the time of the daily meals of the laity is regarded as sacred.

(Schmidt 2001:236-37 - emphasis added)

How did all this preoccupation with purity and sacredness affect ordinary Judeans? Maybe Mark 7:3-4 as both interested in personal purity and a sacred time period had wide application, but for now our focus will shift onto the ritual status of the individual alone. According to Cohen for most Judeans of the second temple period "the sanctification of daily life was not implemented to such a radical degree ... Away from the temple ... most [Judeans] saw no need to observe the purity laws since they were no longer in the 'camp' ..." (Cohen 1987:130). But in contrast to Israelite religion, one of the hallmarks of Judeanism was the extension of purity laws to the laity away from the Temple (Schmidt 2001:231; cf Schürer et al 1979:475). In the Second Temple period there is evidence of ritual baths or miqva'ot (singular miqveh), found all over Palestine and not only in priestly contexts (cf Reich 2002; Eshel 2000; Meyers 2000). It was one important or essential means to maintain a life of purity (cf Sanders 1992:222-229). Sanders (1992:218-224, 228-29) therefore has a different view. Many people, he argues, regarded purity as a positive good. It could have been that the first part of Numbers 19:20 was seen as a positive commandment: "remove corpse impurity". This is based on Antiquities 3.262 where remaining corpse-impure for longer than seven days required the equivalent of a sin offering. So remaining impure was seen as a transgression. Ritual immersion was also extended to be applicable to women. According to Leviticus, contact with semen only required the passage of time for the purification of women, while it requires both the passing of time and bathing for men. But in our period it was agreed that both men and women had to bathe, or rather, immerse themselves for purification.

Ritual immersion, however, did not only revolve around the issue of avoiding transgression. Stegemann \& Stegemann (1999:143) also point to another reason why Judeans ritually immersed themselves. Because of the presence of Gentiles in Palestine and the pagan or semi-pagan governing structures "the urgency of an identity-preserving delineation was not exactly small". Schmidt (2001:239) also points out that due to the proximity of Gentiles after the Hasmonean period it lead to a "transformation and reinforcement of that separation [i e between Judean and Gentile]. It was spatial; it becomes ritual. Because, established in the house, the foreigner is declared 'impure'." Certainly, ritual immersion and washings would have been a meaningful way of maintaining your own position within the Judean symbolic universe and separating yourself from alien elements. What the soreg in the 
Temple symbolised became concrete in ritual immersion. Schmidt (2001:244) explains it succinctly:

In the old system, the categories structuring the thinking of the Temple had as their first function to determine the sphere of holiness within the [Judean] community. While retaining this function, the new system thus modified acquires a new one: that of keeping the foreigners outside the community by establishing a hedge between [Judeans] and [non-Judeans]. Being no longer either territorial or political, the necessary separation between [Judeans] and [non-Judeans], that allows the community to protect itself from the danger of profanation that they impose on it, is henceforth symbolic and ritual (emphasis original).

\subsection{Specific impurities}

Lastly, other dimensions of the purity system need to be discussed. The Tanak of course informed purity regulations. In what is to follow, an overview of the "change in status" that affected ordinary life will be done and how "deviance" from the perfect order of Creation, and indeed, of Judean ethnic identity, was restored to normality.

- Corpse impurity is treated in Numbers 19 and it describes a ritual for purification as well. A red heifer was slaughtered and burned by a priest outside the Temple. The ashes were then mixed with water. Those who had corpse impurity were sprinkled with the mixture on the third day and the seventh, remembering this impurity required seven days of purification. Also on the seventh day those concerned immersed and washed their clothes, and so the impurity was removed. Also the room where the corpse had lain and all the objects within it had to be sprinkled. It is difficult to see how this law applied to those living far from Jerusalem. According to Josephus, a person who remained corpse-impure for more than seven days was required to sacrifice two lambs. One was burned while the other went to the priest (Ant 3.262). The Tanak does not prescribe this requirement. Sanders (1992:218) suggests that for those who lived far away from the Temple it was thought that they transgressed the purity laws "inadvertently", which required a sin offering (Lv 4:27-35) at the first occasion of visiting Jerusalem.

- Childbirth resulted in a long period of impurity that was divided into two stages. The first stage lasted for a week if the child was a boy, and two 
weeks if a girl. The mother was understood to be impure as if she was menstruating, thus sexual relations were forbidden. It may well be that the mother underwent ritual immersion at the end of the first stage. ${ }^{15}$ The second stage lasted for thirty-three or sixty-six days, depending on the child's gender. Here she was not allowed to touch "holy things" (Lv 12:4), that is, food that was destined for the Temple. The impurity ended with the presentation of either a lamb as a burnt offering and a bird (pigeon or dove) as a sin offering, or alternatively, two birds if she could not afford a lamb (Lv 12:1-8).

- Menstruation resulted in a seven day state of impurity. After the seven days the menstruant immersed. Anything she touched like her bed or chair would also become impure, which also required washing. As for those who touched her bed or chair, they had to immerse and wash their clothes and were impure until sunset (Lv 15:19-23). According to Sanders (1992:229), the Pharisees were of the opinion that the ordinary people were not that reliable to avoid this secondary (or midras) impurity. Sexual intercourse during menstruation was strictly forbidden, but if it was inadvertent, the man also became impure for seven days (Lv 15:24). Both parties owed a sin offering in this scenario (Lv 4:27-5:13).

- Irregular discharges concerned discharges from male and female genitalia (Lv 15:1-15, 25-30). These impurities were equivalent to menstruation in the way that impurity was transferred, but as it was more severe than menstruation, purification also required sacrifices, the passing of seven pure days, and immersion.

A man who had a nocturnal emission had to immerse and wash everything that came into contact with the semen. Impurity ended at sunset (Lv 15:16f). After sexual intercourse, both the man and woman were impure. Here purification required immersion, and impurity ended at sunset (Lv 15:18).

- Carcasses of animals (including "swarming things") also resulted in impurity. Impurity ceased at sunset without immersion (Lv 11:29f). Dead swarming things (e. g. rodents, weasels, lizards and crocodiles

\footnotetext{
${ }^{15}$ Laws of purification after childbirth are mentioned in Jubilees (Jub 3:8-14), but here is no mention of ritual immersion as such.
} 
etc) rendered moist food, liquids, vessels and ovens impure (Lv 11:328).

- The main category remaining is leprosy. This did not only refer to leprosy as such, but also to any kind of skin condition (Lv 13-14) impurity was transferred to clothing and houses (Lv 13:47-59; 14:3353). Purification required the inspection of a priest and sacrifices. To turn our modern conception of purity on its head, if a person was entirely covered in "leprosy", a priest would pronounce the "leper" pure (Lv 13:13)! His "change of status" ended, or his skin no longer suffered an improper mixture (Sanders 1992:220).

\section{SUMMARY}

Paul lamented that most of his fellow Judeans had rejected the Messiah, nevertheless, he still admitted that they had zeal for God (Rm 10:2). This of course translates into a zeal for their own ethnic identity. Above it was investigated how their identity shaped, and was shaped by Judeanism's unique religion and covenantal practices related to the Temple, the synagogue, and the home. Socialization into these spheres of life helped to foster a strong Judean consciousness. Socialization (i e the formation of "habitual dispositions" and the role of "categorization") had two aspects to it.

First, socialization was naturally guided by the requirements of the Torah. Here traditional religion and covenantal praxis maintained their function to create a sense of community for those who participated therein. The average Judean would have been socialized into a world where Yahweh alone was worshipped in the Temple, of pilgrimages, tithes and sacrifices/offerings, where the Law and prophets were read and expounded in the synagogue/assembly on the Sabbath, and where the Torah regulated everyday life at home. The purity and holiness of the Temple and the functions related thereto, such as that of the high priest, had to be protected. This went hand in hand with the protection of Jerusalem against foreign religious-cultural elements. The synagogue/assembly became the natural extension of the "thinking" of the Temple. It was also a means for punishment and excommunication whereby the perceived integrity of Judean society could be maintained. At home, mainly the Shema, food and purity regulations contributed towards fostering a Judean consciousness, but also others things such as prayers, dress, and Sabbath observance.

Second, at the same time socialization was influenced by Judeanism's need to resist the unwelcome presence of the Roman Empire, the rule of the Herodians, and the presence of the foreigner in the ancestral land. The latter 
combined to stimulate "primordial" sentiments which lead to strong attachments with elements of Judean culture that was perceived to come under threat. It also led to an intensification or (re)construction of religiouscultural practices to help delinieate those who properly belong from those who do not. As symbolised by the soreg in the Temple complex, the separation between Judean and Gentile, being no longer political and territorial, was transformed to become a ritual affair. Purity rules were extended to make an even deeper impact in everyday life. This was most visibly expressed by ritual immersion/washings, but also by the Judean attitude towards food, especially so among the sects.

One must be wary of romanticising first century Judeanism, but overall, they constituted a unique and tenacious identity in antiquity. Because of socialization, the combination of religion and covenantal praxis involved the objectification of religious-cultural practices in the recognition and communication of affinity and difference vis-à-vis other peoples which ensured that the people of the covenant continued to be a most recognizable ethnic identity in the ancient world.

\section{Works Consulted}

Avigad, N 1990. Jerusalem flourishing - A craft center for stone, pottery and glass, in Shanks, H \& Cole, D P (eds), Archaeology and the Bible: The best of BAR, Vol 2. Archaeology in the world of Herod, Jesus and Paul, 78-95. Washington, DC: Biblical Archaeology Society.

Baumgarten, A L 1997. The flourishing of Jewish sects in the Maccabean era: An interpretation. Leiden: Brill.

BDAG 2000. A Greek-English Lexicon of the New Testament and other Early Christian literature, 3rd ed of BAGD, rev by Danker, F W. Chicago, IL: University of Chicago Press.

Ben-Dov, M 1990. Herod's mighty temple mount, in Shanks, H \& Cole, D P (eds), Archaeology and the Bible: The best of BAR, Vol 2. Archaeology in the world of Herod, Jesus and Paul, 21-30. Washington, DC: Biblical Archaeology Society.

Bourdieu, P 1977. Outline of a theory of practice. Cambridge: Cambridge University Press.

Bull, R J 1990. Caesarea Maritima - The search for Herod's city, in Shanks, H \& Cole, D P (eds), Archaeology and the Bible: The best of BAR, Vol 2. Archaeology in the world of Herod, Jesus and Paul, 106-22. Washington, DC: Biblical Archaeology Society.

Cohen, S J D 1987. From the Maccabees to the Mishnah. Philadelphia, PA: Westminster.

Cromhout, M \& Van Aarde, A 2006. A socio-cultural model of Judean ethnicity: A proposal. HTS 62(1), 69-101. 
Cromhout, M [2007]. Covenantal nomism as a "symbolic universe". Forthcoming in HTS Theological Studies.

De Vos, G 1975. Ethnic pluralism: Conflict and accommodation, in De Vos, G \& Romanucci-Ross, L (eds), Ethnic identity: Cultural continuities and change, 541. Palo Alto: Mayfield.

Dunn, J D G 1990. Jesus, Paul and the law: Studies in Mark and Galatians. Louisville, KY: Westminster John Knox.

Eshel, H 2000. They're not ritual baths. BAR (26)4, 42-45.

Esler, P F 2003. Conflict and identity in Romans: The social setting of Paul's letter. Minneapolis, MN: Fortress.

Evans, C A 1992. Opposition to the temple: Jesus and the Dead Sea Scrolls, in Charlesworth, J H (ed), Jesus and the Dead Sea Scrolls, 235-53. New York: Doubleday.

Feldman, L H 2001. Financing the Colosseum. BAR 27(4), 20-31, 60-61.

Hengel, M 1989. The "Hellenization" of Judaea in the first century after Christ tr by Bowden, J. London: SCM Press.

Horsley, R A 1995. Galilee: History, politics, people. Valley Forge, PA: Trinity Press International.

Horsley, R A 1996. Archaeology, history and society in Galilee: The social context of Jesus and the Rabbis. Valley Forge, PA: Trinity Press International.

Jenkins, R 1997. Rethinking ethnicity: Arguments and explorations. London: Thousand Oaks.

Jones, S 1997. The archaeology of ethnicity: Constructing identities in the past and present. London: Routledge.

Kloppenborg Verbin, J S 2006. The Theodotos synagogue inscription and the problem of first-century synagogue buildings, in Charlesworth, $\mathrm{J} \mathrm{H}$ (ed), Jesus and Archaeology, 236-82. Grand Rapids, MI: Eerdmans.

Malina, B J 1993. The New Testament world: Insights from cultural anthropology, rev ed. Louisville, KY: Westminster.

Meyers, E M 2000. Yes, they are. BAR 26(4), 46-49, 60-61.

Neusner, J 1973. From politics to piety: The emergence of Rabbinic Judaism.

Englewood Cliffs: Prentice Hall.

Milgrom, J 1983. Of hems and tassels. BAR 9(3). (BAR CD Archive:1975-2001.)

Reich, $\mathrm{R}$ 2002. They are ritual baths. BAR 28(2), 50-55.

Pilch, J J 1997. Are there Jews and Christians in the Bible? HTS 53(1\&2), 119-125.

Porter, S E 1994. Jesus and the use of Greek in Galilee, in Chilton, B and Evans, C A (eds), Studying the historical Jesus: Evaluations of the state of current research, 123-54. Leiden: EJ Brill.

Ritmeyer, K \& Ritmeyer, L 1990. Reconstructing Herod's temple mount in Jerusalem, in Shanks, H \& Cole, D P (eds), Archaeology and the Bible: The best of BAR, Vol 2. Archaeology in the world of Herod, Jesus and Paul, 31-61. Washington, DC: Biblical Archaeology Society.

Sanders, E P 1992. Judaism: Practice and belief 63 BCE-66 CE. London: SCM.

Sanders, J A 2002. The family in the Bible. BTB 32(3), 117-28.

Schmidt, F 2001. How the temple thinks: Identity and social cohesion in Ancient Judaism, tr by Crowley, J E. Sheffield: Sheffield Academic Press. 
Schürer, E 1973-1987. The history of the Jewish people in the age of Jesus Christ (175 BC-AD 135), 3 vols in 4 parts, rev \& ed by $G$ Vermes, $F$ Millar and $M$ Goodman. Edinburgh: T \& T Clark.

Scott, G M 1990. A resynthesis of the primordial and circumstantial approaches to ethnic group solidarity: towards and explanatory model. Ethnic and Racial Studies 13(2), 147-71.

Shanks, H 1990. Excavating in the shadow of the Temple Mount, in Shanks, $\mathrm{H}$ \& Cole, D P (eds), Archaeology and the Bible: The best of BAR, Vol 2. Archaeology in the world of Herod, Jesus and Paul, 2-20. Washington, DC: Biblical Archaeology Society.

Shanks, H 2001. Is it or isn't it - A synagogue? BAR 27(6), 51-57.

Smith, A D 1994. The politics of culture: Ethnicity and nationalism, in Ingold, T (ed), Companion Encyclopedia of Anthropology, 706-33.

Stegemann, E W \& Stegemann, W 1999. The Jesus movement: A social history of its first century, tr by Dean, O C. Edinburgh: T\&T Clark.

Strange, J F \& Shanks, H 1990. Synagogue where Jesus preached found at Capernaum, in Shanks, H \& Cole, D P (eds), Archaeology and the Bible: The best of BAR, Vol 2. Archaeology in the world of Herod, Jesus and Paul, 200207. Washington, DC: Biblical Archaeology Society. 